\title{
Little genetic divergence of the greater horseshoe bat Rhinolophus ferrumequinum from far-eastern Asia, with a preliminary report on genetic differentiation of $R$. ferrumequinum from Eurasia and northern Africa examined from cytochrome $b$ sequences
}

\author{
Hung Sun Koh*, Jae Eun Jo, Jang Geun Oh, Gu Hee Kweon, Na Hyon Ahn, \\ Wan Ho Sin \& Dong Seon Sin
}

\begin{abstract}
We obtained cytochrome $b$ complete sequences (1140 bp) of the greater horseshoe bat Rhinolophus ferrumequinum from Korea (Jeju Island and mainland Korea), and these sequences were compared to corresponding sequences of $R$. ferrumequinum, obtained from GenBank, in order to examine genetic divergence among populations within $R$. ferrumequinum from far-eastern Asia and other parts of the range. Specimens from four populations in far-eastern Asia (Jeju, mainland Korea, northeastern China, and Japan) formed a far-eastern clade and were little differentiated, indicating that our results support a former subspecies classification, recognized $R$. f. korai and $R . f$. quelpartis as synonyms of $R$. f. nippon. In addition, we found that the eastern China clade from Henan is genetically distinct from the far-eastern clade, although individuals from Japan, northeastern China, and eastern China are known as R. f. nippon, and we propose further analyses with additional specimens from China to examine whether or not the eastern China clade is a subpopulation within $R . f$. nippon. On the other hand, R. ferrumequinum from Eurasia and northern Africa was found to be composed of four clades (far-eastern Asia, eastern China, central China, and western Asia - Europe - northern Africa), and average nucleotide distances between the first and other three clades were $2.15 \%, 4.10 \%$, and $5.37 \%$ respectively. Thus, we found that genetic distances between these clades are correlated with geographic distances between them, and we concluded that further analysis of cytochrome $b$ and other markers from additional specimens of $R$. ferrumequinum across distributional range is necessary to reexamine its population structure and subspecies classification.
\end{abstract}

KEY WORDS: Genetic divergence, population differentiation, DNA systematics, cytochrome $b$ gene, Rhinolophus ferrumequinum, far-eastern Asia.

Hung Sun Koh [syskoss@chungbuk.ac.kr], Research Institute for Biological Resources, Sejong 339-941, Korea; Jae EunJo [libertecj@naver.com], Research Institute for Biological Resources, Sejong 339-941, Korea; Jang Geun Oh [ojg6532@korea.kr], Research Center of Environment, Jeju 690-170, Korea; Gu Hee Kweon [apodemus@hotmail.com], Research Institute for Biological Resources, Sejong 339-941, Korea; Na Hyon Ahn [multi017@naver.com], Research Institute for Biological Resources, Sejong 339-941, Korea; Wan Ho Sin [sinano@paran.com], Research Institute for Biological Resources, Sejong 339-941, Korea; Dong Seon Sin [snowni@empal.com], Research Institute for Biological Resources, Sejong 339-941, Korea.

Незначительная генетическая дивергенция внутри большого подковоноса Rhinolophus ferrumequinum восточной Азии, и предварительное сообщение о генетической дифференциации $\boldsymbol{R}$. ferrumequinum Евразии и северной Африки по результатам анализа цитохрома $b$

\author{
Хан Сан Ко*, Зае Еун Зо, Зан Гён О, Гу Хи Квон, На Хюн Ан, Ван Хо Син, \\ Донг Сеон Син
}

РЕЗЮМЕ. Мы получили полные последовательности гена цитохром $b$ (1140 пн) большого подковоноса Rhinolophus ferrumequinum из Кореи (о-в Чеджу и континентальная Корея) и сравнили эти последовательности с последовательностями $R$. ferrumequinum из Генбанка, с целью исследовать генетическое расхождение между популяциями $R$. ferrumequinum Дальнего Востока и других частей ареала. Экземпляры из четырех популяций восточной Азии (Чеджу, континентальная Корея, северо-восточный Китай и Япония) образуют одну слабо подразделенную дальневосточную кладу, 
поддерживая, таким образом, предшествующую подвидовую систему, рассматривающую $R . f$. korai и R.f. quelpartis как синонимы R.f. nippon. Дополнительно, мы обнаружили, что восточно-китайская клада из провинции Хэнань генетически отличается от дальневосточной клады, хотя все экземпляры из Японии, северо-восточного и восточного Китая обычно относят к $R$. $f$. nippon. Мы считаем необходимым провести дополнительный анализ с привлечением нового материала для проверки того, является ли восточно-китайская клада субпопуляцией внутри $R . f$. nippon. С другой стороны, $R$. ferrumequinum Евразии и северной Африки формируют четыре клады (дальневосточную, восточнокитайскую, центрально-китайскую и объединяющую экземпляры из западной Азии, Европы и северной Африки); средние генетические дистанции между первой кладой и остальными тремя составляют 2,15\%, 4,10\% и 5,37\% соответственно. Таким образом, мы обнаружили, что генетические дистанции между этими кладами соответствуют географическим расстояниям между ними и заключили, что необходим дополнительный анализ цитохрома $b$ и других генетических маркеров с привлечением большего материала по R. ferrumequinum со всего ареала для исследования популяционной и подвидовой структуры вида.

КЛЮЧЕВЫЕ СЛОВА: генетические различия, популяционные различия, ДНК систематика, цитохром $b$, Rhinolophus ferrumequinum, Дальний Восток.

\section{Introduction}

Simmons (2005) noted that geographic distribution of the greater horseshoe bat Rhinolophus ferrumequinum (Schreber, 1774) extends from Japan through China and Europe to northern Africa, and among 32 nominal subspecies listed, she recognized seven valid subspecies: R. f. ferrumequinum, R. f. nippon, $R$. f. korai, $R$. $f$. tragatus, R. f. proximus, $R$. $f$. irani, and $R$. $f$. creticum. However, previously Corbet (1978) reported that $R$. ferrumequinum is composed of six subspecies (R.f. ferrumequinum, $R$. f. nippon, $R$. f. tragatus, $R . f$. regulus, $R$. $f$. proximus, and $R$. $f$. irani), and Woon (1967) noted $R$. ferrumequinum from Jeju as a separate subspecies R.f. quelpartis. Later Benda \& Vallo (2012) stated that $R$. ferrumequinum is tentatively considered as a species complex, composed of western $R$. ferrumequinum and eastern $R$. nippon, indicating that subspecies and species classifications in $R$. ferrumequinum are still controversial.

Molecular genetic studies for taxonomic reconsideration have become widespread during the past decades, and mitochondrial DNA (mtDNA) is a highly sensitive genetic marker suitable for studies of closely related taxa or populations of a variety of species (Sunnucks, 2000). Based on cytochrome $b$ and control region sequences Patrick et al. (2013) examined biogeography of the genus Rhinolophus, and noted that $R$. ferrumequinum lineages from Yunnan and Japan diverge about 3.58 million years ago. In addition, population fragmentation and limited dispersal of $R$. ferrumequinum from Britain and two areas in continental Europe were found from microsatellite analyses (Rossiter et al., 2000), and low genetic diversity of $0.07 \%$ $0.62 \%$ was reported among 11 cytochrome $b$ complete haplotypes of $R$. ferrumequinum from Honshu and Kyushu in Japan (Sakai et al., 2003). Recently, five major lineages of R.ferrumequinum: Europe and Africa; western Asia; central China (Shaanxi and Sichuan); eastern China (Anhui, Jiangxi, Shandong, and Henan); and Japan (including two samples from Beijing and Jilin), were recognized from mtDNA ND2 gene and microsatellite analyses (Flanders et al., 2009). The further study of the same markers (Flanders et al., 2011) reported three lineages in East Asia: central China lineage from Shaanxi, Sichuan, Yunnan, and Hubei; eastern China lineage from Anhui, Jiangxi, Shandong, Henan, Hubei, and Beijing; and Japan lineage from Japan, Jilin, and Shandong. We found that both results are not consistent in the designation of the eastern China and Japan lineages (i.e., from their successive studies the Beijing sample, recognized initially as the Japan lineage, moved to the eastern China lineage, and the Shandong samples, found initially as the eastern China lineage, moved to both eastern China and Japan lineages).

On the other hand, Lopez et al. (1997) reported that regarding evolutionary rates, the cytochrome $b$ gene vary at a slower rate than the control region and ND2, and Flanders et al. (2009, 2011) noted that further sampling of $R$. ferrumequinum from northern China and Korea is needed before colonization pattern in fareastern Asia can be fully resolved. Thus, it is necessary to obtain sequences of conservative cytochrome $b$ gene from Korean $R$. ferrumequinum specimens in order to reexamine population differentiation of $R$. ferrumequinum from far-eastern Asia and other regions as well.

In this study, we first obtained 12 complete sequences (1140 bp) of mtDNA cytochrome $b$ gene of $R$. ferrumequinum from Jeju Island and mainland Korea, and these sequences were compared to corresponding haplotypes of $R$. ferrumequinum, obtained from GenBank, in order to reexamine genetic divergence among populations of $R$. ferrumequinum in far-eastern Asia and other Eurasia and northern Africa.

\section{Material and methods}

For this analysis, we collected 12 specimens from five locations in Korea (Table 1, Fig. 1). Small pieces of muscle tissues were taken and preserved in a deep freezer. 
Table 1. Location and specimen IDs (with GenBank ID and cytochrome $b$ haplotype ID in parenthesis) of 12 specimens of Rhinolophus ferrumequinum from Korea, used in this study.

\begin{tabular}{|l|l|}
\hline Location & Specimen IDs \\
\hline Jeju Island & Rh2562, Rh2564, and Rh2566 (KP063140, CB01JjJeju), Rh2563 \\
Jeju & (KP063141, CB02JjJeju), Rh2565 and Rh2567 (KP063142, CB03JjJeju) \\
Mainland Korea & Rh2568 (KP063143, CB03NjKorea) \\
Mt. Naejang & Rh2551 and Rh2553 (KP063144, CB01CjKorea), Rh2552 (KP063145, \\
Cheongju & CB02CjKorea) \\
Yeongweol & Rh2569 (KP063146, CB04YwHcKorea) \\
Hwacheon & Rh2570 (KP063146, CB04YwHcKorea) \\
\hline
\end{tabular}

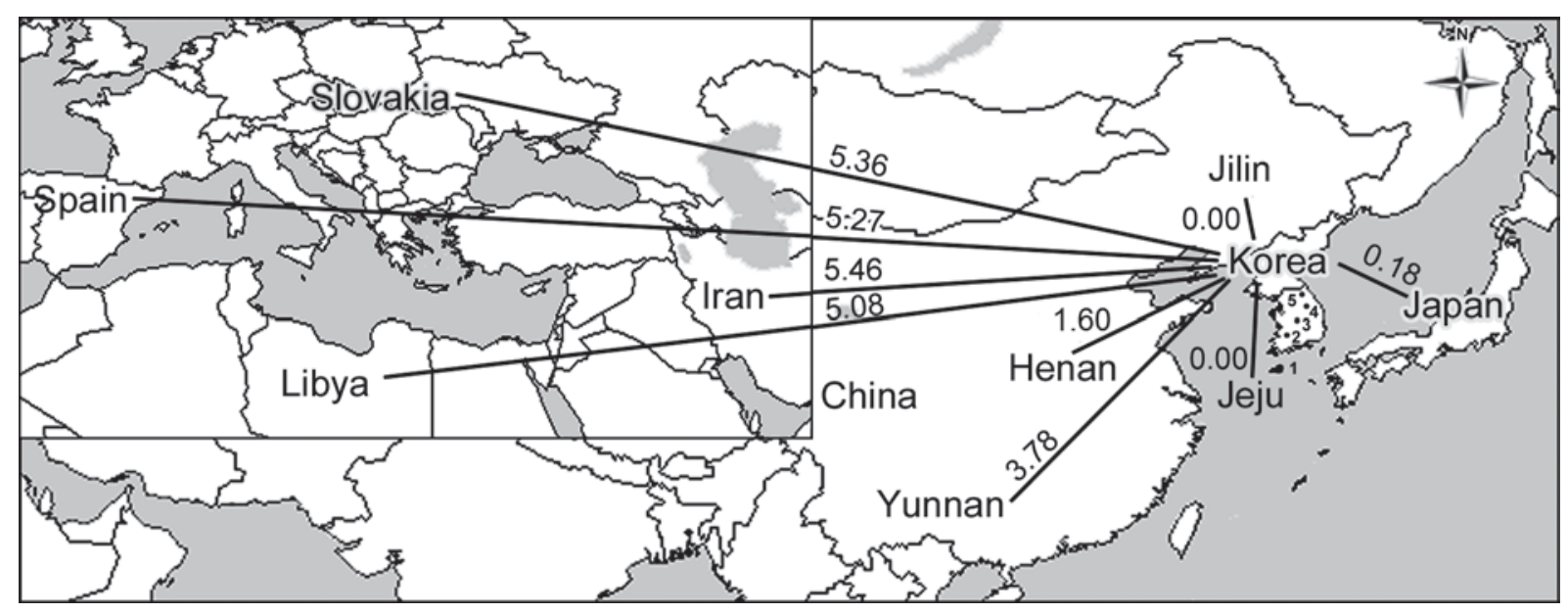

Figure 1. Collection sites of 12 Rhinolophus ferrumequinum specimens from five locations in Jeju Island and mainland Korea, used in this study. For locations names refer to Table 1. Minimum Jukes-Cantor nucleotide distances for cytochrome $b$ gene (\%) between haplotypes from mainland Korea and other haplotypes from nine regions (namely Jeju, northeastern China, Japan, Henan, Yunnan, Iran, Spain, Slovakia, and Libya) are given above the lines, connecting Korea and other regions.

Total cellular DNA was extracted using a genomic DNA extraction kit (Intron Co., Seoul, Korea). For DNA amplification of the cytochrome $b$ gene, the primers L14724 and H15915 (Irwin et al., 1991) were used, and the PCR thermal cycle was as follows: $94^{\circ} \mathrm{C}$ for 5 $\min ; 94^{\circ} \mathrm{C}$ for $1 \mathrm{~min}, 55^{\circ} \mathrm{C}$ for $1 \mathrm{~min}, 72^{\circ} \mathrm{C}$ for $1 \min (30$ cycles); $72^{\circ} \mathrm{C}$ for $5 \mathrm{~min}$. To remove primer and unincorporated nucleotides, the amplified product was purified using a DNA PrepMate kit with a silica-based matrix (Intron Co.). The purified PCR products were analyzed with an automated DNA Sequencer (Perkin Elmer 377) at Bioneer Co. (Seoul, Korea).

Twelve cytochrome $b$ complete sequences of $R$. ferrumequinum from Jeju and mainland Korea were obtained for this study, and these sequences were compared to 22 corresponding sequences of $R$. ferrumequinum from Eurasia and northern Africa, obtained from GenBank, as given in Table 2.
Sequence alignment, detection of parsimonious informative sites, model selection, calculation of nucleotide distances, and tree constructions with 1000 bootstrapped replications were conducted using MEGA5 (Tamura et al., 2011): maximum likelihood tree was constructed using the Jukes Cantor (JC) model, which showed the lowest Bayesian information criterion scores, and was chosen by MEGA5 as the best model for our data. Rhinolophus affinis (EF544421), R. pusillus (EF544425), Hipposideros ruber (FJ347996), and Murina leucogaster (AB085733) were used as outgroups.

\section{Results}

Seven haplotypes were identified from 12 cytochrome $b$ complete sequences of $12 R$. ferrumequinum specimens from five locations in two regions Korea (Jeju Island and mainland Korea), and their GenBank 
Table 2. GenBank IDs of 22 cytochrome $b$ complete haplotypes (1140 bp) of Rhinolophus ferrumequinum, used in this study.

\begin{tabular}{|l|l|}
\hline Location & Accession number \\
\hline Jeju Island, Korea & NC020326 \\
Kwangweon, mainland Korea & JN392460 \\
Jilin, northeastern China & DQ351847 \\
Honshu and Kyushu, Japan & AB085721 \\
& AB085724, AB085726, AB085727, AB085728, AB085729, \\
Honshu, Japan & AB085731 \\
& EF544400, EF544401, EF544406, EF544410, EF544416, \\
Henan, eastern China & EF544417 \\
Yunnan, central China & EU434936, DQ297575 \\
Iran, western Asia & KC579396 \\
Spain, Europe & EU436673 \\
Slovakia, Europe & KC579400 \\
Libya, northern Africa & KC579398 \\
\hline
\end{tabular}

accession numbers are KP063140-KP063146, as given in Table 1. Within 29 haplotypes of $R$. ferrumequinum (seven haplotypes from this study and 22 haplotypes from GenBank), 119 sites (10.4\%) were variable, and 94 sites $(8.31 \%)$ were parsimonious informative.

From the 17 cytochrome $b$ haplotypes of $R$. ferrumequinum in the four populations of far-eastern Asia, average JC distance between four haplotypes from Jeju (three from this study and one from GenBank) and five haplotypes from mainland Korea (four from this study and one from GenBank) was $0.12 \%$ (range $0.00-0.18 \%$ ). Average JC distance between nine haplotypes from Jeju and mainland Korea and one haplotype (DQ351847) from northeastern China was $0.06 \%$ (range $0.00-0.09 \%$ ), and the northeastern Chinese haplotype was identical to three (NC020326 from Jeju and JN392460 and CB04YwHcKorea from mainland Korea) of the nine haplotypes from Jeju and mainland Korea. Additionally, average JC distance between ten haplotypes from Jeju, mainland Korea, and northeastern China, with within group average JC distance of $0.11 \%$, and seven haplotypes from Japan, with within group average JC distance of $0.17 \%$, was $0.29 \%$ (range $0.18-0.35 \%$ ).

A maximum likelihood tree constructed on the basis of the 29 cytochrome $b$ haplotypes of $R$. ferrumequinum from Eurasia and northern Africa is shown in Figure 2. Four subgroups were recognized: 17 haplotypes from Jeju, mainland Korea, northeastern China, and Japan in far-eastern Asia (Gp 1; far-eastern subgroup); six haplotypes from Henan in eastern China (Gp 2; eastern China subgroup); two haplotypes from Yunnan in China (Gp 3; central China subgroup); and four haplotypes from western Asia, Europe, and northern Africa (Gp 4; western Asia-Europe-northern Africa subgroup). The average JC distances between the fareastern subgroup (Gp 1) and other three subgroups (Gps 2, 3, and 4) were 2.15\%, 4.10\%, and 5.37\%, respectively. Additionally, minimum intergroup JC distances between haplotypes from mainland Korea and other haplotypes from nine regions (Jeju, northeastern China, Japan, Henan, Yunnan, Iran, Spain, Slovakia, and Libya) were $0.00 \%, 0.00 \%, 0.18 \%, 1.60 \%, 3.78 \%$, $5.46 \%, 5.27 \%, 5.36 \%$, and $5.08 \%$, respectively. These JC distances are given above the lines, connecting Korea and other regions, in Figure 1.

\section{Discussion}

Island populations should diverge over time (genetically and morphologically) from populations of respective mainland species (Johnson et al., 2000), although at the end of the last glacial period, large areas of continental shelf were dry land, facilitating exchange of plant and animal species by land bridge connections to what are now isolated islands (Lomolino et al., 2010). In addition, a classification should be the product of all available characters distributed as widely and evenly as possible over the organisms studied (Huelsenbeck et al., 1996), and most biologists would prefer to see DNA sequence information as a supplement to, rather than as a replacement for, morphological data (Mallet \& Willmott, 2003).

Average JC distance between four cytochrome $b$ haplotypes of $R$. ferrumequinum from Jeju and five

Figure 2. A maximum likelihood tree constructed using 29 complete cytochrome $b$ haplotypes (1140 bp) of Rhinolophus ferrumequinum. The tree was constructed with 1000 bootstrapped replications, and the bootstrap values $>50 \%$ are reported at the internodes. 


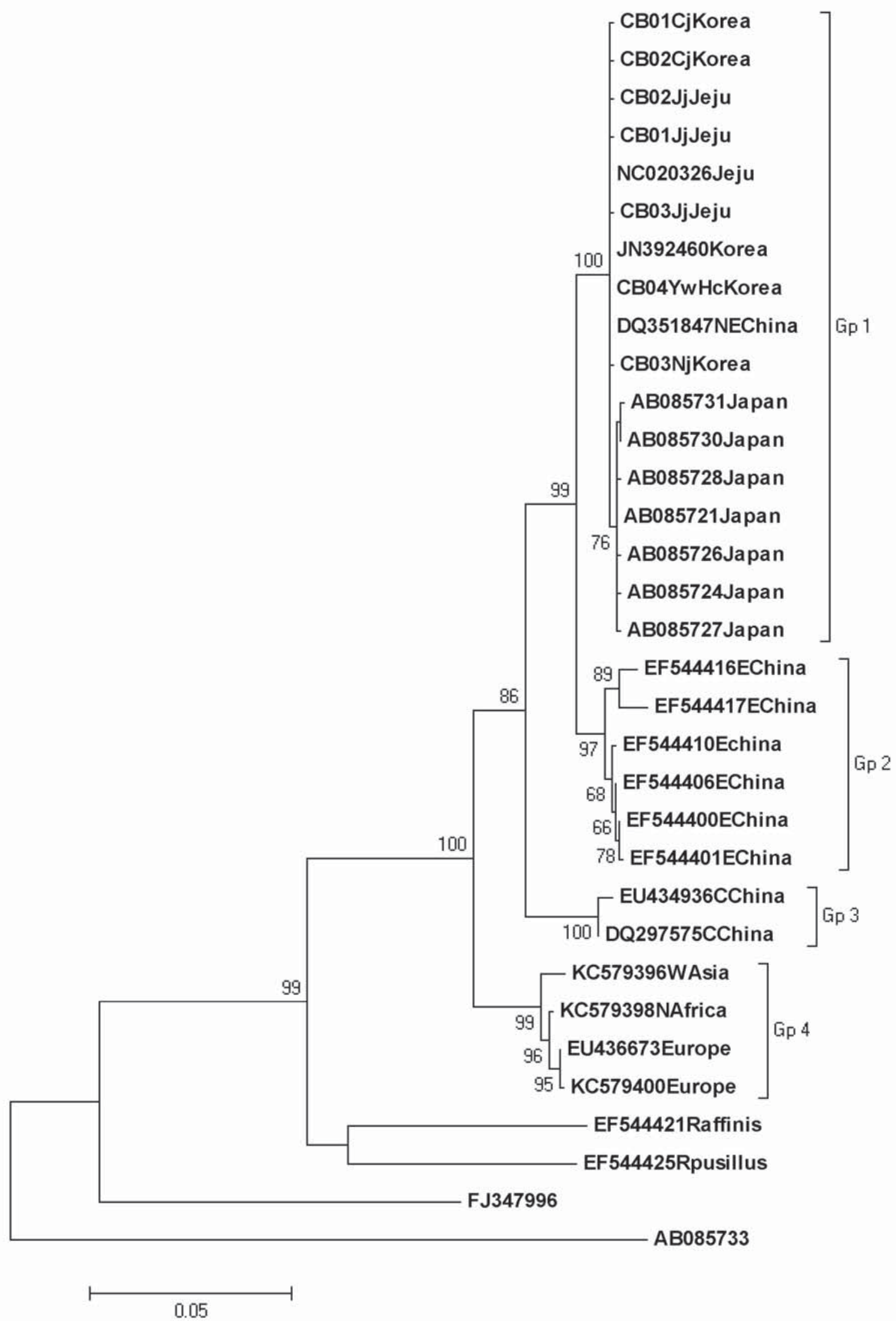


haplotypes from mainland Korea within the Gp 1 was $0.12 \%$ (Fig. 2); one Jeju specimen shares haplotype with two of five analyzed individuals from mainland Korea. Thus, we newly detected that insular Jeju population is not divergent from mainland Korean population. We considered that Jeju population has been in contact to mainland Korean population, probably, during the last glacial period, and that our sequencing results do not support a previous subspecies classification by Woon (1967), reported $R$. ferrumequinum from Jeju as a separate subspecies $R . f$. quelpartis.

In addition, Flanders et al. (2009) noted the sequence divergence of $0.47 \%$ between eastern Chinese population (Beijing and Jilin) and Japanese population of $R$. ferrumequinum on the basis of ND2 and microsatellite analyses. In the present cytochrome $b$ sequencing study with $R$. ferrumequinum (Fig. 2), average JC distance between ten haplotypes from Jeju, mainland Korea, and northeastern China and seven haplotypes from insular Japan was $0.29 \%$ (range $0.18-0.35 \%$ ), and these 17 haplotypes from Jeju, mainland Korea, northeastern China, and Japan formed the single far-eastern clade (Gp 1), indicating that insular Japanese population is not divergent from Jeju Island and mainland Korean populations in this marker.

Furthermore, peripheral populations are often genetically and morphologically divergent from central populations, while natural barriers to dispersal, which limit species distribution, include mountain ranges and rivers (Goldberg \& Land 2007). Northern boundary of the Korean Peninsula is formed naturally by Yalu River, Baitou Mountain (the main peak of the Changbai Mountains in northeastern China, $2744 \mathrm{~m}$ above sea level), and Tumen River. However, in this cytochrome $b$ sequencing study of $R$. ferrumequinum (Fig. 2), average JC distance between one northeastern Chinese haplotype and nine Korean haplotypes within the Gp 1 was $0.06 \%$. The northeastern Chinese haplotype was identical to three of the nine haplotypes from Korea, indicating that mainland Korean population is not diverged from adjacent northeastern Chinese population. Probably, the northern boundary of the Korean Peninsula does not play a role of a natural barrier to limit free dispersal of the greater horseshoe bat. Thus, we concluded that genetic differentiation among the four populations in far-eastern Asia is negligible. We also found that our sequencing results do not support current subspecies classification by Simons (2005), recognizing separately R.f. korai (Korea) and R.f. nippon (Japan), and support a former subspecies classification by Corbet (1978), recognized $R$.f. korai and $R$.f. quelpartis as synonyms of $R$. f. nippon.

Furthermore, in this study (Fig. 2) we found that an eastern China clade from Henan (Gp 2) is distinct from both the far-eastern Asia clade (Gp 1) and the central China clade ( $\mathrm{Gp} \mathrm{3}$ ). This result contradicts both to Corbet (1978), who classified $R$. ferrumequinum from the whole China, except Yunnan area, Korea, and Japan as R.f. nippon, and Simons (2005) who mentioned only
R.f. korai and R.f. nipppon from the Far East. Since we recognized the greater horseshoe bats from Japan, northeastern China, and eastern China as one subspecies $R$. $f$. nippon, and we found the individuals from eastern China were distinct from this group, we propose further analyses with additional specimens from China to determine whether or not the eastern China clade is a subpopulation within $R$. f. nippon.

On the other hand, Dillon (1984) reported that a great body of evolutionary theory predicts that genetic divergence between pairs of populations should be positively correlated with inter-population distance, and Hardy \& Vekemans (1999) noted that isolation by distance is the process by which geographically restricted gene flow generates a genetic structure. We found that average JC distances between the far-eastern clade (Gp 1) and other three clades (Gp 2, eastern China clade; Gp 3, central China clade; and Gp 4, western Asia-Europe-northern Africa clade) are gradually increased according to geographic distances, from $2.15 \%$ between the geographically nearest clades (Gp 1 and 2) to $5.37 \%$ between two farthest clades (Gp 1 and 4) through $4.10 \%$ between two geographically intermediate clades (Gp 1 and 3). Minimum JC distances among $R$. ferrumequinum populations were also varied in cline from east to west, as shown in Figure 1. We newly found correlation between geographic distance and genetic clades in $R$. ferrumequinum, and our present results on population subdivision of $R$. ferrumequinum appeared to be consistent with an isolation-by-distance model, reported by Wright (1943). In conclusion, we consider that further analyses with cytochrome $b$ and other genetic markers from more numerous specimens of $R$. ferrumequinum across distributional range are necessary to perform in order to reexamine its subspecies classification and population structure.

\section{References}

Benda P. \& Vallo P. 2012. New look on the geographical variation in Rhinolophus clivosus with description of a new horseshoe bat species from Cyrenaica, Libya // Vespertilio. Vol.16. P.69-96.

Corbet G.B. 1978. The Mammals of the Palaearctic Region. London: British Museum, Cornell University Press. $314 \mathrm{p}$.

Dillon R.T. 1984. Geographic distance, environmental difference, and divergence between isolated populations // Systematic Zoology. Vol.33. P.69-82.

Flanders J., Jones G., Benda P., Dietz C., Zhang S., Li G., Sharifi M. \& Rossiter S.J. 2009. Phylogeography of the greater horseshoe bat, Rhinolophus ferrumequinum: contrasting results from mitochondrial and microsatellite data // Molecular Ecology. Vol.18. P.306-318.

Flanders J., Li W., Rossiter S.J. \& Zhang S. 2011. Identifying the effect of the Pleistocene on the greater horseshoe bat, Rhinolophus ferrumequinum, in East Asia using ecological niche modeling and phylogenetic analyses // Journal of Biogeography. Vol.38. P.439-452. 
Goldberg E.E. \& Land L. 2007. Species and dispersal barriers // American Naturalist. Vol.170. P.297-304.

Hardy O.J. \& Vekemans X. 1999. Isolation by distance in a continuous population: reconciliation between spatial autocorrelation analysis and population genetics models // Heredity. Vol.83. P.145-154.

Huelsenbeck J.P., Bull J.J. \& Cunningham C.W. 1996. Combining data in phylogenetic analysis // Trends in Ecology \& Evolution. Vol.11. P.152-157.

Irwin D.M., Kocher T.D. \& Wilson A.C. 1991. Evolution of the cytochrome $b$ gene of mammals // Journal of Molecular Evolution. Vol.32. P.128-144.

Johnson K.P., Adler F.R. \& Cherry J.L. 2000. Genetic and phylogenetic consequences of island biogeography // Evolution. Vol.54. P.387-396.

Lomolino M.V., Riddle B.R., Whittaker R.J. \& Brown J.H. 2010. Biogeography. Sunderland, MA: Sinauer Associates Inc. 878 p.

Lopez J.V., Culver M., Stephens C., Johnson W.E. \& O’Brien S.J. 1997. Rates of nuclear and cytoplasmic mitochondrial DNA sequence divergence in mammals // Molecular Biology \& Evolution. Vol.14. P.277-286.

Mallet J. \& Willmott K. 2003. Taxonomy: renaissance or Tower of Babel // Trends in Ecology \& Evolution. Vol.18. P.57-59.

Patrick L.E., McCulloch E.S. \& Ruedas L.A. 2013. Systematics and biogeography of the arcuate horseshoe bat species complex (Chiroptera, Rhinolophidae) // Zoologica Scripta. Vol.42. P.553-590.

Rossiter S.J., Jones G., Ransome R.D. \& Barratt E.M. 2000. Genetic variation and population structure in the endangered greater horseshoe bat Rhinolophus ferrumequinum // Molecular Ecology. Vol.9. P.1131-1135.

Sakai T., Kikkawa Y., Tsuchiya K., Harada M., Kanoe M., Yoshiyuku M. \& Yonekawa H. 2003. Molecular phylogeny of Japanese Rhinolophidae based on variations in the complete sequences of the mitochondrial cytochrome $b$ gene // Genes \& Genetic Systems. Vol.78. P.179-189.

Simmons N.B. 2005. Order Chiroptera // Wilson D.E. \& Reeder D.M. (eds). Mammal Species of the World. A Taxonomic and Geographic Reference. Third edition. Baltimore: Johns Hopkins University Press. P.312-529.

Sunnucks P. 2000. Efficient genetic markers for population biology // Trends in Ecology \& Evolution. Vol.15. P.199203.

Tamura K., Peterson D., Peterson N., Stecher G., Nei M. \& Kumar S. 2011. MEGA5: Molecular evolutionary genetic analysis using maximum likelihood, evolutionary distance, and maximum parsimony methods // Molecular Biology \& Evolution. Vol.28. P.2731-2739.

Woon P.H. 1967. [Illustrated Encyclopedia of Fauna and Flora of Korea. Vol. 7. Mammals]. Seoul: Samwha Publishing Co. P.301-306 [in Korean].

Wright S. 1943. Isolation by distance // Genetics. Vol.28. P.114-128. 